\title{
Making Crime News: Newspapers, Violent Crime and the Selective Reporting of Old Bailey Trials in the late Eighteenth Century
}

Peter King

\section{(2) OpenEdition}

\section{Journals}

Electronic version

URL: https://journals.openedition.org/chs/695

DOI: $10.4000 /$ chs. 695

ISSN: 1663-4837

\section{Publisher}

Librairie Droz

\section{Printed version}

Date of publication: 1 March 2009

Number of pages: $91-116$

ISBN: 978-2-600-01295-9

ISSN: 1422-0857

\section{Electronic reference}

Peter King, "Making Crime News: Newspapers, Violent Crime and the Selective Reporting of Old Bailey Trials in the late Eighteenth Century", Crime, Histoire \& Sociétés / Crime, History \& Societies [Online], Vol. 13, n¹ | 2009, Online since 01 March 2012, connection on 22 March 2022. URL: http:// journals.openedition.org/chs/695 ; DOI: https://doi.org/10.4000/chs.695 


\title{
Making Crime News:
}

Newspapers, Violent Crime and the Selective Reporting
of Old Bailey Trials in the late Eighteenth Century

\author{
Peter King
}

Comment concevait-on l'information sur le crime et la justice pénale à la fin du XVIII siècle? Cet article compare les archives des sessions de l'Old Bailey (principale cour criminelle londonienne) et la couverture des procès de cette juridiction par la presse londonienne pour examiner de quelle manière les journaux faisaient leur choix entre les différents types de procès et meurtres. Il mesure l'impact du sexe, du statut social et de la notoriété des auteurs comme des victimes, l'importance du caractère dramatique de l'affaire, de son contenu sexuel, de l'humour et des peurs sociales plus larges dans l'appréciation du caractère médiatique des affaires. Ce faisant, il propose une vision différente du changement des attitudes à l'égard de la violence. À l'époque, comme maintenant, les procès impliquant une violence létale étaient les plus susceptibles d'être chroniqués, mais au XVIII siècle la plupart des meurtres n'obtenaient pas une couverture plus approfondie que d'autres crimes capitaux. Par contre, il y avait une forte corrélation entre le détail de la couverture de presse et la peine encourue. Si le meurtre ne suscitait pas toujours des articles plus longs, la probabilité que le procès s'achève sur l'échafaud était un critère indéniable d'intérêt médiatique.

How was crime and justice news constructed in the late eighteenth century? This paper uses a comparison between the Old Bailey Sessions Papers and the London newspapers' coverage of Old Bailey trials to analyse newspaper selection policies across all categories of trial, and across different types of murder cases. It measures the impact of the gender, social status and notoriety of both victim and accused, as well as the role of dramatic struggles, sexual content, humour and broader social fears in decisions about newsworthiness. In doing so it offers a different perspective on changing attitudes to violence. Then, as now, trials that involved lethal violence were much more likely to be reported than any other category, but in the eighteenth century most murders were given no deeper coverage than other capital crimes. There was, however, a very high correlation between the penalty imposed by the court and the depth of reporting. Murder did not always attract longer news coverage in the late eighteenth century but the possibility that a trial would end with death on the gallows was undoubtedly a key criterion of newsworthiness.

Peter King is Professor of History at the Open University. His publications include Crime, Justice and Discretion in England 1740-1820 (Oxford, 2000) and Crime and Law in England, 1750-1840: Remaking Justice from the Margins (Cambridge, 2006). He is currently engaged on a study of race in the criminal trial during the late eighteenth and early nineteenth centuries. 
lthough recent criminological studies in Britain, Europe and America have $\mathrm{A}_{\text {analysed in detail the nature, and potential impact, of the media's reporting }}$ of crime and criminal justice issues, and although considerable work with a nineteenth - or twentieth-century focus has also been done ${ }^{2}$, historians working on the eighteenth century have given relatively little attention to the ways such issues were reported in the period's key medium of information exchange - the newspaper. Some work has been done on the reporting of individual cases. Donna Andrew and Randall McGowen, for example, have brilliantly exploited the newspapers in their analysis of the famous 1770s forgery case involving the Perreaus and Mrs Rudd, and the London newspapers' role in fuelling a widespread panic about one offender, the so-called 'Monster', in 1790 has also been explored by several historians ${ }^{3}$. Moreover historians have studied a few specific - and usually very brief - periods in eighteenth- and early nineteenth-century England during which either the provincial or the London newspapers helped to create panics about violent robbery ${ }^{4}$, while Clive Emsley has uncovered evidence of a similar newspaper-led panic about night-time robbery in Paris in $1826^{5}$. However, broad-based overarching research on the extent, role and nature of all the different types of law and order news that were reported in the eighteenth century has only just begun to appear in print, most notably in the articles on different parts of England by Esther Snell and by the author of this article recently published in a special issue of Continuity and Change ${ }^{6}$. Moreover this more systematic research has so far been largely confined to work on the English newspapers, reflecting in part the relatively slow development of newspapers in some European countries during the eighteenth century. In France, for example, Paris did not have a regular daily newspaper until the later $1770 \mathrm{~s}^{7}$ but the situation in England, and especially in London - which will be the main focus of this article - was very different. The number, size and frequency of publication of the capital's newspapers grew very rapidly from 1700 onwards and by the later eighteenth century these papers were by far the most important sources of 'law and order' news for the city's inhabitants.

The newspapers did not have a monopoly, of course. Other types of printed material such as trial reports and execution broadsheets were also available, and first hand experience of crime offered individuals and small communities sporadic and occasional direct insights. However, by the final quarter of the eighteenth century it was in the newspapers that the vast majority of the English population gained most of their information about the prevalence of crime and the ways the criminal justice system was dealing with t $^{8}$. In the mid 1780 s London alone boasted nine dailies and

2 For a recent guide to the modern criminological work see Reiner (2002, pp. 381-383). Large numbers of nineteenth and twentieth century studies use newspapers extensively in relation to particular topics within the history of crime - see for example such classic studies as Pearson (1983), Walkowitz (1992); Davis (1980); The most recent additions to British work in this area include Conley (2007); Abbott (2005); McMahon (2008); King ( 2003); Emsley (2008); Wardle (2006).

3 Andrew, McGowen (2001); Bondeson (2001); Shoemaker (2004); Smith (1999).

$4 \quad$ King (1987); Rogers (1992); Rawlings (1999); Statt (1995).

5 Emsley (2007), 145.

6 King (2007); Snell (2007).

$7 \quad \operatorname{Ruff}(2001$, pp. 26-27.

8 Shoemaker $(2004$, p. 249); on the decline of other forms of printed material about crime see McKenzie (2007, pp.152-155); Devereaux (2003). 
eight tri-weeklies, as well as an average of nine weekly papers. The following decade saw further rapid growth. The number of provincial newspapers in circulation rose from fifty to over seventy, and in London fifteen daily newspapers were being produced by the mid 1790s ${ }^{9}$. As Snell and King's work has shown, these papers carried a large amount of law and order news. In 1790, for example, the average London paper filled about 15 per cent of its newshole (i.e. of that part of the paper not dedicated to advertising) with stories broadly relating to crime, justice and the criminal law. In The Times the figure was around 20 per cent and an even higher percentage has been found in the Kentish Post around mid-century ${ }^{10}$. However, although these historians have developed a fairly detailed analysis of the overall structure and content of law and order news in both the London and provincial newspapers, an analysis which has highlighted the central role played by both victim's reports of unsolved crimes and by trial reports within this category of news, we still know very little about the processes by which crime and justice news was constructed $^{11}$. The primary aim of this paper is to analyse those processes through a detailed investigation of one important aspect of late eighteenth-century law and order news reporting - the highly selective ways in which the London newspapers reported trials at the Old Bailey. It will then use this detailed analysis to explore late eighteenth-century ideas about the newsworthiness of different types of crime stories, and the continuities and discontinuities between these ideas and those used by modern crime reporters. In particular it will focus on role of violence - both that committed by the perpetrators and that committed by the state on the gallows - in the decisions editors made about which stories were printed and about the depth of coverage each would be given. By doing so it will approach the extensive interrelated historiographical debates about changing attitudes to both interpersonal violence and to capital punishment in this period ${ }^{12}$ from a new angle, and will suggest that - in contrast to the modern pattern - the penalties attached to various crimes may have been as important, or perhaps even more important, than the crime itself in deciding its newsworthiness.

Like all forms of reporting, crime news is not just collected or discovered - it is manufactured. By selecting certain items from the vast number of potentially newsworthy materials available, those responsible for the editing process assemble a final product which, though it is dependent for its existence on the availability of suitable raw materials, does not inevitably - or even usually - reflect with any accuracy the range or nature of those materials. Making crime news, even at this initial stage before any interpretative writing or editorialising has been done, is a highly

9 Barker (1998, pp. 23, 111); Werkmeister (1967, pp. 22, 163).

10 Snell (2007, pp. 19-21); King (2007, pp. 73-112). Definitional problems make comparisons difficult but the proportion of news devoted to crime and justice issues is not dissimilar in modern studies see, Reiner (2002, pp. 381-383).

11 Snell (2005); King (2007); Snell (2007).

12 See for example McGowen (1989, 1986, pp. 312-334); McGowen (2007) and his discussion of the role of the press in McGowen (2004, pp. 210-231); King (2006, pp. 227-280); Carter Wood (2004); Spierenburg (2001, pp. 87-105). 
creative process ${ }^{13}$. Unfortunately, however, it is often completely impossible for the eighteenth-century historian to gain access to the selection process. This task is by no means easy even today. However contemporary criminologists can at least sit in a newsroom and analyse how media gate keepers such as newspaper or television editors select which particular pieces of news they will report from the vast range of items that come to them from police sources, from the public or from those they pay to report on events such as court hearings etc. As a result modern studies have, for example, been able to analyse moments when new crime themes are identified and the ways in which some of those themes then develop into fully-fledged crime waves $^{14}$. Historians very rarely have such opportunities, however. For most categories of crime and justice reporting we will never know how many (or what kind of) items the editor/printer of an eighteenth-century newspaper had access to, but then chose not to report to the public.

This is particularly problematic, for example, in relation to one of the most important categories of reports - those involving victim's accounts of unsolved crimes. In the five papers I have sampled for 1790 these brief stories took up around 15 per cent of the total newshole devoted to crime stories and in purely numerical terms represented 24 per cent of all crime-related stories - making it likely that they played an important role in shaping readers ideas about crime and its prevalence ${ }^{15}$. However, the picture they painted was almost certainly severely distorted by the attitudes and selection policies of the newspapers' editors and by the dynamics of their relationship to their potential sources. Over half of the victim's reports of unsolved crimes published in these five newspapers in 1790 related to violent highway robberies alone. However, only about 6 per cent of major court cases involved accusations of robbery ${ }^{16}$ and other more scattered contemporary sources, such as diaries and magistrates notebooks, make it equally clear that minor thefts and assaults vastly outnumbered robberies. In trying to ascertain how this severely distorted reporting of unsolved crimes came about we are, however, very severely handicapped by the sources. No self-report studies of crime victims are available until the last third of the twentieth century. Nor do we have any record of the potentially large subset of unsolved crime reports which victims sent to eighteenth-century newspaper editors but which did not end up being reproduced in print. We can speculate, of course. It was clearly not in the interests of newspaper editors to report a typical sample of these offences and as a result it seems highly likely that they severely distorted the pattern of unsolved crimes in two ways. First, they almost certainly ignored the vast majority of the reports of minor crimes sent in to them, whilst simultaneously prioritising the publication of many of the violent robbery reports they received. Secondly, by reinforcing the idea, either directly or indirectly, that

13 Chibnall (1977, p. ix); Jewkes (2004, p. 37); Cohen, Young (eds) (1973, p. 95).

14 Fishman (1981).

15 On the important role played by victim's reports see also Snell (2007, p. 29); King (2007, pp. 88-89, 108). On average in The Times, World, Public Advertiser and London Chronicle sampled in January and July 1790, 15 per cent of crime related newshole was taken up by reports of unsolved crimes, 6 per cent by reports of summary proceedings, 5 per cent by provincial assizes, 32 per cent by Old Bailey Proceedings, 9 per cent by other London courts - the London Sessions and Kings Bench, and 33 per cent by a vast range of various other crime related reports such as those describing arrests, hangings, escapes, etc.

16 King (2007, p. 89). 
minor thefts were not sufficiently newsworthy, they probably discouraged a higher proportion of minor theft victims from sending in reports in the first place. We will never know the precise role that newspaper editors' decisions about unsolved crime reports had in distorting law and order news in the late eighteenth century. However, for at least one important category of crime reporting - the often very substantial reports of Old Bailey trials which regularly appeared in the papers - a much more systematic analysis of newspaper selection policies can be constructed and the rest of this article will therefore concentrate on exploring these.

Because (unlike the summary courts, or City/Middlesex sessions courts) a separate printed record is available of almost every Old Bailey petty jury felony trial in this period, in this vital court at least it is possible to compare newspaper coverage directly with the full range of events which the papers could have chosen to report. By the late eighteenth century the so-called 'Old Bailey Sessions Papers' had effectively become the authorities' formal record of the proceedings in the only court in London with the right to try capital felonies such as murder, rape and highway robbery. They therefore provide a very useful basis from which to measure the proportions of each type of criminal trial that were reported in the newspapers as well as making available a relatively full (if by no means complete) account of the trial itself, which can then be compared with the content of the newspaper's reports ${ }^{17}$. This gives us an unparalleled opportunity to study how newspaper reporting mechanisms operated, the extent to which they favoured the reporting of specific types of crime, and in particular the degree to which they may have given more space to certain violent crimes.

Equally important for our purposes here, events at the Old Bailey usually attracted extensive newspaper coverage. The vast majority of eighteenth-century newspapers reported at least some Old Bailey trials in considerable detail. In the two periods in 1790 that I have sampled in detail, for example, up to a third of the newshole devoted to crime and justice issues arose from reports of Old Bailey trials ${ }^{18}$. Coverage was extremely patchy and selective, as Simon Devereaux has recently shown, and it also varied across time as crime-related items in general vied for space with other types of news. When the news from France was especially exciting, for example, editors would almost certainly have cut down on the number of trial reports they published. However, the Old Bailey was clearly a very rich source of news in this period, and as a result in all the five papers sampled the overall proportion of crime news being printed greatly increased during the periods when the Old Bailey was sitting - the average increase being over 40 per cent ${ }^{19}$. Precisely how each newspaper gained access to Old Bailey trial reports is difficult to trace, but by

17 By the late eighteenth century the Old Bailey Sessions Papers published at least a brief description of almost all the felony trials that came before the court. Exceptions where occasionally made if the evidence was considered unduly salacious (see King, forthcoming), and for a brief period in the early 1790s acquittals were also excluded, Devereaux (1996, pp. 492-493). The sessions papers were not, of course, full transcripts. For a good discussion of their selectivity see Shoemaker (2008).

18 King $(2007$, pp. 86-87, 108). Old Bailey trial reports in the newspapers were usually very much longer than the average crime-related report hence the fact that, while they represented only 11 per cent of reports, they took up a three times larger proportion of the newshole, Devereaux (2007, pp. 1-12).

19 The Times, World, Public Advertiser and London Chronicle were sampled in January and July 1790 and The Argus for January 1790. This was done both during periods when the Old Bailey was sitting (or had sat the previous day) and periods when it was not. On average core crime news increased its share of newshole by nearly half from 8.8 per cent to 13.1 per cent. 
the later eighteenth century the papers were no longer waiting, as they had done earlier in the century, until the Old Bailey Sessions Papers were out and then selectively copying from them. Instead they now published their own reports well before the Sessions Papers were printed, and often in the case of the dailies within twenty-four hours of the trial itself. They appear to have obtained these accounts from independent trial reporters, some of whom, the printer of the Sessions Papers noted in the 1780 s, could be regularly seen in the public gallery of the Old Bailey 'taking down the trials for publication'. One or two of the reporters may have worked for individual papers, and Simon Devereaux has found evidence that The Times may even have got draft reports from the writer of the Old Bailey Sessions Papers himself. However, most reports were probably produced by independent reporters who sold their copy to any newspaper that would buy it. The editors would presumably then make their own choice about which trials they were interested in ${ }^{20}$.

In this paper I have used a comparison between the Old Bailey Sessions Papers and the coverage of Old Bailey trials in a range of London newspapers selected for their typicality and for their range of political backgrounds, to look both at newspaper selection policies across all categories of Old Bailey trial, and at the specific approaches they took to trials involving various kinds of murder accusations. The broad aim here was to analyse not only the pattern of selection - which kinds of cases attracted reports and which were given the deepest coverage - but also the ideas about newsworthiness that those patterns imply. For example, was the degree of violence involved always a key factor - as some studies of late twentieth-century newspapers have suggested ${ }^{21}$ - and what impact did the gender, age and social status of the accused and/or the victim have on the level of newspaper trial reporting? Overall, therefore, the broad aim is to present a case study of the ways crime news was made, the criteria on which selection was based, and the continuities and discontinuities in those criteria between the late eighteenth century and the late twentieth.

\section{II}

Given the immense amount of material available, a carefully tailored sampling technique had to be used. Six diverse and reasonably accessible newspapers (five dailies from a spectrum of political persuasions and one tri-weekly - The London Chronicle) were sampled for one single Old Bailey sessions in January 1790 and three papers deemed to be reasonably representative were then analysed for all of 1790 - i.e. for all eight of the Old Bailey sessions that year. Following this, one of the more generous papers from the point of view of crime reporting, The Times, was then studied for a different year - 1786 - to check the typicality of 1790 . Following this all murder cases heard at the Old Bailey over a ten-year period (1785-1794) were then followed up in the same newspaper. In January 1790 all the six newspapers sampled were highly selective in their use of Old Bailey trials but there were also significant differences between papers ${ }^{22}$. The Times and The Argus reported at

20 Devereaux (2007, pp. 5-6).

${ }^{21}$ Reiner (2002, pp. 383-384).

22 A similar pattern was found by Devereaux across the period 1780-1800 for a range of 5 dailies and 5 tri-weeklies, Devereaux (2007, pp. 6-7). 
least a minimal amount of the evidence produced at 12.8 per cent of the 132 trials that took place at the Old Bailey, the World, the Gazetteer and the London Chronicle reported between 4.5 and 6.1 per cent, and the Public Advertiser a mere 1.5 per cent $^{23}$. The latter offered a brief outline of the charges, verdicts and sentences of most of the accused, a very routine form of reporting, but it very rarely gave any details about the trials themselves. Other papers offered less wide coverage of the charges and outcomes but reported a much more significant proportion of trials in some detail. Just over 80 per cent of 1790 trials went unreported in any of the six papers sampled. Five percent were reported in only one paper and none were reported in all six. Given that only one murder and a couple of other severely violent offences were tried at the January sessions, in the next stage of the research three reasonably representative papers were then researched for the whole of 1790 .

This study of The Times, The World and The London Chronicle revealed consistent patterns of selection by the newspapers (see Tables 1A and 1B). Overall 16.3 per cent of the cases that are recorded in the Old Bailey Sessions Papers for 1790 were reported in at least one of the three papers sampled, but the levels of reporting varied massively across the five main categories of offences used here. (Table 1A; Column 3). Only 9.6 per cent of the cases involving direct theft without the use of violence reached the pages of at least one of these papers. Theft accompanied by violence - i.e. highway robbery - achieved an above average rating of 22 per cent. Somewhat surprisingly perhaps over two fifths of indirect appropriations - coining, forgery, fraud, receiving - were reported. The vast majority of cases (77 per cent) involving non lethal violence - rape, aggravated assault, assault on a customs officer, riot, and arson found their way into at least one of the papers, whilst all the year's lethal violence cases - nine murders, one manslaughter charge and one infanticide were given coverage. Within these broad categories there were significant differences between offences (Table 1B). In the direct theft category, for example, simple non-capital larceny had a very low reportage rate at 6.5 per cent. Forms of theft that did not involve violence but were still capital offences such horse theft, shoplifting and housebreaking achieved rather higher levels. The same was true within the indirect appropriation category. The non-capital offence of receiving was given very low coverage whilst the capital offences of coining and forgery were covered in over 70 per cent of cases (Table 1B).

There were clearly deliberate selection policies at work. In March 1790, for example, The Times, after reporting one highway robbery trial from the Old Bailey, then noted that 'several other prisoners were convicted of larcenies but none of a nature sufficiently interesting to merit insertion, ${ }^{24}$. Moreover similar selection policies were used by all the three papers sampled. Every paper surveyed followed the same broad pattern giving massively more coverage to violent offences than to

23. I have defined a trial report here as any report that contains more detail than just the name of the offender, the crime for which he/she was indicted and the verdict/punishment. Even a short summary or comment on the evidence in addition to the above resulted in classification as a trial report although the vast majority of such reports contained much more detail.

24 Times, 1 March 1790 . The same policies were pursued by provincial papers. 'We hope to be able to give an account of the proceedings in both courts', the Chelmsford Chronicle announced ten years later, 'as far as they may be any ways interesting to the public or entertaining to our readers', Chelmsford Chronicle, 6 July 1801. 
Table 1A and 1B: Reporting of Old Bailey Trials Jan-Dec 1790

Data from three Newspapers Combined

\begin{tabular}{|c|c|c|c|c|}
\hline \multicolumn{5}{|l|}{ Table 1A. Groups of Offences } \\
\hline & $\begin{array}{c}\text { No. of cases } \\
\text { in Old Bailey } \\
\text { Sessions Papers }\end{array}$ & $\begin{array}{l}\text { Cases reported } \\
\text { in } 1 \text { or more } \\
\text { of the } 3 \text { papers }\end{array}$ & $\begin{array}{l}\text { \% OBSP cases } \\
\text { reported in } 1 \\
\text { or more paper }\end{array}$ & $\begin{array}{c}\text { Ave size } \\
\text { of newshole } \\
\text { devoted to } \\
\text { to each report }\end{array}$ \\
\hline $\begin{array}{l}\text { Property Crime, Direct Theft } \\
\text { Property Crime, Highway Robbery } \\
\text { Property Crime,Indirect Appropriation } \\
\text { Non-Lethal Violence } \\
\text { Lethal Violence } \\
\text { Misc Crimes } \\
\text { Total }\end{array}$ & $\begin{array}{r}698 \\
63 \\
71 \\
18 \\
11 \\
23 \\
884\end{array}$ & $\begin{array}{r}67 \\
14 \\
31 \\
14 \\
11 \\
7 \\
144\end{array}$ & $\begin{array}{r}9.6 \\
22.2 \\
43.7 \\
77.8 \\
100.0 \\
30.4 \\
16.3\end{array}$ & $\begin{array}{l}0.37 \\
0.60 \\
0.54 \\
1.76 \\
0.58 \\
0.65 \\
0.62\end{array}$ \\
\hline \multicolumn{5}{|l|}{ Table 1B. Individual Offences } \\
\hline $\begin{array}{l}\text { Stealing } \\
\text { Privately Stealing from person or shop } \\
\text { Horse or Sheep Stealing } \\
\text { Burglary, Housebreaking } \\
\text { Highway Robbery, Robbery } \\
\text { Receiving } \\
\text { Coining Offences } \\
\text { Forgery and Uttering Forged Notes } \\
\text { Fraud, False Pretences, Extortion } \\
\text { Rape } \\
\text { Aggravated Assault including riot and affray } \\
\text { Assault on Customs officer } \\
\text { Violence to property-arson/animal maiming } \\
\text { Murder } \\
\text { Manslaughter } \\
\text { Infanticide } \\
\text { Treason (incl stone throwing at King) } \\
\text { Buggery } \\
\text { Bigamy } \\
\text { Other Miscellaneous offences }\end{array}$ & $\begin{array}{r}555 \\
43 \\
8 \\
92 \\
63 \\
23 \\
18 \\
10 \\
20 \\
3 \\
3 \\
8 \\
4 \\
9 \\
1 \\
1 \\
1 \\
2 \\
7 \\
13\end{array}$ & $\begin{array}{r}36 \\
13 \\
3 \\
15 \\
14 \\
2 \\
14 \\
7 \\
8 \\
3 \\
2 \\
5 \\
4 \\
9 \\
1 \\
1 \\
1 \\
1 \\
3 \\
2\end{array}$ & $\begin{array}{r}6.5 \\
30.2 \\
37.5 \\
16.3 \\
22.2 \\
8.7 \\
77.8 \\
70.0 \\
40.0 \\
100.0 \\
66.7 \\
62.5 \\
100.0 \\
100.0 \\
100.0 \\
100.0 \\
100.0 \\
50.0 \\
42.9 \\
15.4\end{array}$ & $\begin{array}{l}0.44 \\
0.29 \\
0.23 \\
0.31 \\
0.60 \\
0.25 \\
0.41 \\
0.72 \\
0.55 \\
0.20 \\
2.25 \\
0.78 \\
3.55 \\
0.55 \\
0.43 \\
0.10 \\
1.37 \\
0.30 \\
0.49 \\
0.30\end{array}$ \\
\hline Total & 884 & 144 & 16.3 & 0.62 \\
\hline
\end{tabular}

property offences and giving the most complete coverage to cases involving lethal violence (Table 2). In 1790, as the overall figures for coverage in at least one of the three papers indicate, (Column 3 Table 1B) trials involving homicide were 15 times more likely to be reported than simple larcenies, and six times more likely to be reported than the average for all types of offence. Very similar ratios were found in 1786. In that year The Times was 19 times more likely to report a murder case than a simple non-capital larceny trial, and ten times more likely to report a murder trial than the average for all types of trial. Equally, highway robbery trials were about three times more likely to be reported than simple larcenies just as they were in $1790^{25}$.

25 Based on a complete survey of The Times for every Old Bailey sessions in 1786. It is interesting to note however that indirect appropriation and non-lethal violence cases were only about twice as well reported as direct thefts not including violence. 
Table 2: Reporting of Old Bailey Trials in Three Individual Newspapers 1790 - Times, World and London Chronicle

\begin{tabular}{|l|c|c|c|c|c|}
\hline Crime Category & $\begin{array}{c}\text { No. of cases } \\
\text { in Old Bailey } \\
\text { Sessions } \\
\text { Papers }\end{array}$ & $\begin{array}{c}\text { \% OBSP cases } \\
\text { reported in 1 } \\
\text { or more papers }\end{array}$ & $\begin{array}{c}\text { \% OBSP cases } \\
\text { reported in the } \\
\text { Times }\end{array}$ & $\begin{array}{c}\text { \% OBSP cases } \\
\text { reported in the } \\
\text { World }\end{array}$ & $\begin{array}{c}\text { \% OBSP cases } \\
\text { reported in } \\
\text { London } \\
\text { Chronicle }\end{array}$ \\
\hline Property Crime, Direct Theft & 698 & 9.6 & 6.6 & 5.7 & 2.0 \\
Property Crime, Highway Robbery & 63 & 22.2 & 20.6 & 6.3 & 7.9 \\
Property Crime, Indirect Appropriation & 71 & 43.7 & 33.8 & 23.9 & 16.9 \\
Non-Lethal Violence & 18 & 77.8 & 61.1 & 38.9 & 50.0 \\
Lethal Violence & 11 & 100.0 & 100.0 & 81.8 & 54.5 \\
Misc Crimes & 23 & 30.4 & 26.1 & 8.7 & 13.0 \\
All & 884 & 144 & 12.6 & 8.5 & 5.5 \\
Sample size & 84.3 & 111 & 75 & 49 \\
\hline
\end{tabular}

There is clear evidence here, therefore, that the late eighteenth-century newspapers, like their modern equivalents, were massively more likely to report crimes involving extreme violence, especially if they resulted in the death of the victim. Lethal violence was clearly deemed by the editors to be extremely newsworthy, as to a lesser extent was theft involving violence. If, as seems likely, the editors followed the same selection policies when it came to filtering the many reports of unsolved crimes they received from victims, then this will go a long way to help explain why property crimes involving violence were massively over-represented amongst reports of unsolved crimes compared to their very small role amongst indicted offences. However, the selection and reporting policies of the eighteenthcentury newspapers showed other characteristics which were not directly related to the degree of violence involved in the crime. In all three papers in 1790, and in The Times in 1786, forgery trials were around 10 times better represented than trials for simple non-capital theft. This pattern is not especially surprising. Forgery was a crime for which a much higher proportion of the convicted were sent to the gallows and it also attracted the attention of the middling sort, who were the key target audience of newspaper proprietors, for two other reasons. Not only did it affect middling men and women's commercial dealings, it also brought into the courts, and into the shadow of the gallows, a subgroup of accused much closer to them in social background and experience ${ }^{26}$. Moreover there was only one forgery case on average per sessions whereas on many occasions there were as least ten highway robbers to choose from. Editors seem to have tried to avoid the repetition of too many very similar cases when they made their selections, which may explain why horse or sheep theft trials - which occurred on average only once per sessions - received a higher proportional coverage in 1790 than other more common forms of capital larceny such as burglary. (Table 1B). Coining trials were also very well reported in 1790, although this may have reflected a temporary focus on this type of crime since they

26 For a marvellous case study of the news-making potential of a 1770s forgery case see Andrew, McGowen (2001). Another hugely reported forgery case during that decade involved Dr Dodd, the Chaplain to the King, see Radzinowicz (1948, pp. 450-472). 
were no better represented in the 1786 Times reports than the average for all types of crime cr. $^{27}$.

When we look not just at the percentage of each type of trial that resulted in a report, but also at the depth of reporting, a much more complex picture begins to emerge which implies that newspaper editors were using a much greater range of criteria about potential newsworthiness. The depth of reporting as measured by the amount of columns, or parts of columns, given over to the reporting of the different types of crime tried at the Old Bailey in 1790 is measured in Column 4 of Tables $1 \mathrm{~A}$ and $1 \mathrm{~B}$. As we might expect the lowest levels of coverage were given to thefts not involving violence - especially burglary and horse and sheep stealing. Indirect appropriations like receiving and coining also received fairly small coverage. An average of less than half a column was also given to trials involving rape or buggery but this was very definitely not because they were considered not to be newsworthy. By this point in the eighteenth century the papers made it clear that delicacy towards their readers sensibilities, not to mention the explicit instructions issued by the City authorities, prevented them from reporting such trials at any length ${ }^{28}$. The average murder trial in 1790 was given more than half a column, but not much more. Murder trial reports averaged 0.55 columns compared to the average of 0.62 for all types of trial. Murder reports took up considerably less space on average than forgery reports $(0.72)$, assaults on customs officers $(0.78)$ and even than the subset of highway robbery trials that the newspapers chose to report (0.60). In part, as we will see when we analyse the coverage of different types of murder trial in the next section, this was because 1790 did not witness as many especially newsworthy forms of murder trial as most other years did. In The Times the average column size devoted to murder trial reports across the whole decade from 1785 to 1794 was nearly twice as great as it was in 1790 alone. However, the relatively low depth of coverage of murder trials in 1790 also reflects the fact that a considerable number of other criteria of newsworthiness were clearly at work. If we measure which individual offender's trials attracted the most detailed coverage on aggregate across the three papers, for example, none of the top 10 individuals whose stories were covered in 1790 were murderers. The top ten stories can however be easily linked to the other criteria of newsworthiness modern criminologists have identified in recent crime reporting - i.e. not only the seriousness of the offence but also a series of other elements. These include the presence within the story of a type of offence that has been magnified in the public consciousness by a newspaper led moral panic, the involvement of high status victims or accused, the trial of celebrated criminals, the presence of significant sexual content, and the presence of highly exceptional or idiosyncratic elements or of a degree of humour/irony ${ }^{29}$.

$27 \quad 26$. Only 5 per cent of coining offences were reported in The Times in 1786.

28 Devereaux (1996, p. 491) notes that in 1787 an aldermanic committee specifically laid down that 'No trials of remarkable indecency ... should be published'.

29 Roshier (1973), 49. 
III

The most obvious criteria of newsworthiness - the seriousness of the offence in terms of its potential threat to the lives and property of large number of local people - clearly explains why the biggest crime trial story of the year in 1790 was the conviction of two arsonists who had set fire to property in Aldersgate street in order to rob the neighbouring houses in the resulting confusion. Systematic arson caused widespread fear amongst the close-packed houses of the metropolis and one paper reported that 'the court was filled very early - and every spectator seemed petrified with the enormity of the crime' ${ }^{30}$. This was big news and explains why the arson category in Table 1B attracted the highest average level of coverage in 1790. This trial even outgunned the trial of Renwick Williams, the so-called 'Monster' whose habit of cutting women in the street had caused an extended moral panic in the metropolis and has attracted a large amount of historical attention as a result ${ }^{31}$. Williams alone was chiefly responsible for the fact that the category of aggravated assault scored the second highest level of coverage in Table1A. The next most heavily reported trial that year involved an individual indicted for simple larceny only. However, this involved a celebrity criminal whose reputation went before him. The accused was the well-spoken and outwardly gentlemanly George Barrington, whose eloquence in his own defence, not to mention his habit of challenging jurors, had enabled him to avoid several attempts to convict him for theft and picking gentlemen's pockets over a period of years, thus rendering him a level of notoriety rarely accorded to others of his trade. When, after successful defences in 1784, 1785 and 1789 he finally came to grief and was sentenced to transportation in 1790 his trial was big news ${ }^{32}$.

The two other simple larceny offenders who also found their way into the top ten almost certainly got there because their crime involved humour, an elite victim and an overtly sexual context. This story of the seduction of the ageing Countess of Berghausen by a dashing young Irishman posing as an army Major was simply too good to resist. The countess, whose clerical husband had 'unfortunately after their

30 Old Bailey Sessions Papers available online at [http://www.oldbaileyonline.org] (henceforth $O B S P$ ) 1790, Edward Lowe and William Jobbins, t17901027-17 - this number is that recorded at [oldbaileyonline.org]; Both Times, 1 November 1790 and the London Chronicle 30 October to 2 November 1790 (from which the quote comes) devoted over a page and a half to this trial. The World, 1 November 1790 gave it one and a half columns.

31 OBSP 1790, Renwick Williams, t17901208-54. London Chronicle, 6-8 and 8-10 July 1790 used up 6 columns on the Monster and another two and a half 7-9 December 1790; The World, 5, 8-12 July and 9 December1790; Times, 6, 7 and 9 July and 9 December 1790; Public Advertiser, 8-10 and 21 July1790; The Gazetteer, 9-10 and 13 1790; The Old Bailey brought this offender back before them in the December following, after the resolution of two points of law, but even when these column inches are added he did not quite overtake the two arsonists. For further discussion - Bondeson (2001); Shoemaker (2004, pp. 275-300); Smith (1999).

32 OBSP 1790, George Barrington (t17900915-10), Barrington had been twice convicted and imprisoned in the 1770s - OBSP January 1777 (t17770115-13) and April 1778 (t17780429-103). He was found not guilty of pickpocketing in the same court in February 1784 (t17840225-6) and in December 1789 (t17891209-18), and not guilty of simple larceny in April 1785 (t17850406-13). By 1790 The London Chronicle 16-18 September 1790 accorded him a rare honour - his own headline saying simply 'Barrington'. Times 16 and 18 September 1790 did the same on two occasions - The World 18 September 1790. 
marriage become a lunatic', was putty in the Major's hands. Having lived with her, mistreated her when they were in India and then managed to get back into her good graces, he finally plotted with his lover, a Miss Goldsborough, to remove from her London home 'an immense quantity of India Muslins' and a large amount of money, silver and jewellery while the 'Major' kept her busy with a trip into the provinces. However, the removal aroused suspicion, officers from 'the public office in Poland Street' were called in, and they found the Major and Miss Goldsborough in bed together finalising their plans to take ship for Ireland with a wagon full of goods. The story was made even more attractive by a final twist, for despite the best efforts of the famous barrister, Mr Garrow, the prosecution could not prove precisely who owned the goods. The Major and his accomplices were therefore acquitted much to the joy of some of the papers. The Times for example made it clear that it agreed with the Major that 'if old women would have juvenile dainties, they should be made to pay a high price for them'. Given the multiple elements of newsworthiness that the case included it is not therefore surprisingly that four of the five papers sampled chose to give it extended room in their pages ${ }^{33}$.

Rather surprisingly perhaps the trial of John Frith for throwing stones at the King's coach - for which the charge was treason - was only the fifth most covered story, and received less than a third of the column inches devoted to the two arsonists, perhaps because he was quickly defined as insane and not therefore seen as signifying an ongoing threat ${ }^{34}$. There were, however, some attempts to discuss Frith's background in separate articles and, as with the Monster, it needs to be remembered that for our particular purpose here we have only measured the depth of reporting of the trial itself rather than the total amount of reporting that the papers carried on a specific case. The final two places in the top ten were taken by two separate forgery cases, both of which ended in capital convictions. Forgery cases, to quote the London Chronicle's report on one of these two, often created a situation in which 'curiosity and expectation were so much excited', and the most heavily reported was given extra interest by the fact that it involved Francis Fonton, a highly respected 56 year old man who had been a broker and Bank of England clerk for 20 years before being caught forging a stock receipt ${ }^{35}$.

The failure of any of 10 murder/manslaughter trials reported in 1790 to reach such heights of coverage does not mean, however, that murder trials never achieved similar levels of reporting. It simply indicates that routine murders, while they were almost always reported, were not felt by editors to merit the same depth of coverage as celebrity centred stories, trials that were the culmination of moral panics, or trials that tuned into the deepest fears of the London population about such things as the threat of a widespread fire in the capital's crowded streets. Murder trials did get almost automatic coverage but the depth of that coverage depended very much on the context in which the murder occurred and whether or not the story contained

33 OBSP 1790, John Payne, Robert Loy, Esther Goldsborough (t17900113-102). Times, 19 and 20 January 1790; World, 20 January 1790; London Chronicle, 16-19 January 1790; Argus, 19 January 1790

34 OBSP 1790, John Frith (t17900417-1). World, 19 April 1790; Times, 14, 15, 19, 20 April 1790; London Chronicle, 17-20 April 1790; and Times, 30 October1790; London Chronicle, 28-30 October 1790; World, 30 October 1790 .

35 OBSP, 1790, Francis Fonton (t17900915-37). Times, 20 September 1790; London Chronicle, 18-21 September 1790; World, 20 September 1790 . 
elements that were deemed especially newsworthy. In most years at least one such murder trial took place, and in some several well-reported murder trials occurred. 1790 happens not to be one of them. In three of the ten years 1785-1794 for example the average column space given to each murder trial in The Times was about double that of 1790 . In two other years it was nearly triple that amount. The Times coverage of one specific murder trial in 1787, for example, gave that trial more space than any of the Old Bailey trials it covered in 1790 apart from that involving the arsonists.

The trial in July 1787 of the servant Henrietta Radbourne for murdering her mistress took up about 500 lines in The Times - almost an entire page of closely printed type - and was held over for a day after an enticing reference in the previous days' paper to 'this trial of great importance ${ }^{36}$. Other papers also covered the trial in considerable depth and for very good reasons. The story was a compelling one that would have played on the fears of many of the servant-employing classes. Henrietta had been living for only a week with her mistress, the 70 year old Mary Morgan, who had taken her into service on the basis of a written reference from 'one of those offices with which this city too much abounds'. Mary did not find Henrietta satisfactory and after a week told her they must part as soon as possible. Soon afterwards, after they had got ready for the night, Henrietta, unusually, made a point of asking her mistress if she had said her prayers. About three in the morning Mary was slashed five times across the head with a short bayonet. Her scull was laid bare and she was also badly cut in the hip and elbow. She escaped and cried out for help but died not long afterwards and Henrietta, as the only person in the house at the time, was indicted for her murder. Henrietta claimed she let others into the locked house to do the terrible deed, hoping that the goods she could then steal would help her to get back into favour with the estranged father of her child. This plea did not save her even though the jury came up with a partial verdict. The indictment for petty treason was dropped but, Henrietta was found guilty of murder and after a delay occasioned by the need to settle a legal technicality she was condemned to death ${ }^{37}$. In December Henrietta was hanged for murder in front of a huge crowd outside Newgate - an event recorded in many of the London newspapers as well as in provincial papers such as the Bath Chronicle, and Felix Farley's Bristol Journal ${ }^{38}$. Her body was then sent for dissection to the Surgeon's Hall. The Times had covered the whole of Henrietta's journey in detail from her initial remand while her mistress was still alive, through her later examinations before the Rotation office magistrate, to her trial and hanging ${ }^{39}$. Nor did they stop reporting her movements after she was dead. The day after her hanging when 'a vast concourse of people' gathered in the gallery around the amphitheatre of the Surgeon's Hall to view Henrietta's body. December 1787; Public Advertiser, 15 December 1787; Morning Herald, 15 December 1787;
Morning Chronicle and London Advertiser, 15 December 1787; Gazetteer, 15 December 1787; Felix Farley's Bristol Journal, 22 December 1787; Bath Chronicle, 20 December 1787.

39

OBSP, 1787, t17870711-1. Times, 14 July 1787; 16 and 17 July 1787.

World and Fashionable Advertiser, 16 July 1787; Gazetteer and New Daily Advertiser, 16 July 1787; Morning Chronicle and London Advertiser, 16 July 1787; Public Advertiser, 16 July 1787 all carried reports of the trial although none were as long as that in Times, 16 and 17 July 1787.

Times, 7 and 22 June; 16, 17 and 21 July 1787; 13 and 15 December 1787. 
The Times reported that

one of the skeleton's which was placed in a niche fell down, and caused a consternation better conceived than described, the women fainted and the men were frightened; in a short time however the panic subsided and the place was soon cleared and the skeleton replaced which was that of the black who was executed some time ago for the murder of the maid servant in Rathbone Place ${ }^{40}$.

It was no wonder the newspapers were reluctant to let Henrietta slip away into history. She had made good copy for some months and her trial at the Old Bailey had generated the longest murder trial report found in The Times during the ten years sampled here. On its day nearly half The Times's newshole had been dedicated to it. This is not necessarily surprising. Henrietta's case had all the elements that would appeal to the core readership of The Times. It played into contemporary fears about domestic servants and their power, particularly when the master or mistress lived alone. It spoke of betrayal. It involved a dramatic physical fightback by a very elderly victim. Moreover if the jury had not brought in a partial verdict, but instead found Henrietta fully guilty as charged, it would have played into a very current debate about whether or not women should still be burned at the stake for petty treason because they had killed their masters/mistresses/husbands. Wilberforce had unsuccessfully brought in a bill to end this practice the previous year and a short time later it was indeed abandoned by Parliament ${ }^{41}$.

\section{IV}

No murder trials made as big a splash in The Times as Henrietta's in the decade sampled here. However, four other murder trials took up more than half a page (i.e. over 2 columns) between 1785 and 1794, which would have put each of them in the top five trial reports in 1790 . What kinds of murder trials were selected for large-scale coverage during this period and what types were largely ignored? The vast majority of the 82 murder trials heard at the Old Bailey and recorded in the Old Bailey Sessions Papers between 1785 and 1794 generated at least a small trial report in The Times but its editors clearly saw certain types of case as more newsworthy than others. Murder trials are notoriously difficult to categorise consistently and it also has to be remembered that in the eighteenth-century indictments for murder were brought against offenders, such as negligent drivers causing deaths, who would at other times be tried only for lesser offences such as manslaughter. However, for the purposes of this analysis I have divided these 82 murder trials into 9 main categories (Table 3A) and although the sample sizes can be very small a fairly clear pattern emerges from this exercise.

Those murder indictments which were effectively disguised manslaughter charges relating to deaths by accident - due mainly to reckless driving or popular recreations that got out of hand (such as the bullock-running incident that led to a bystander being gored to death $)^{42}$ received a very low amount of column inches -

\footnotetext{
40 London Chronicle, 18 December 1787; Times, 18 December 1787.

41 Gatrell (1994, p. 317).

42 OBSP, 1786, Thomas Plata and Francis Parker (t17861025-37). Times, 30 October 1786.
} 
Table 3A: Times Coverage of Broad Categories of Murder Trials 1785-94

\begin{tabular}{|c|c|c|c|c|}
\hline Description & $\begin{array}{l}\text { No of cases } \\
\text { in OBSP }\end{array}$ & $\begin{array}{l}\text { Ave Pages } \\
\text { in OBSP }\end{array}$ & $\begin{array}{l}\text { \% reported } \\
\text { in Times }\end{array}$ & $\begin{array}{l}\text { Ave Columns } \\
\text { in Times }\end{array}$ \\
\hline $\begin{array}{l}1 \text { Accidental death due to dangerous } \\
\text { behaviour/neglect }\end{array}$ & 9 & 7,3 & 89 & 0,3 \\
\hline $\begin{array}{l}2 \text { Death/Murder arising from fight in } \\
\text { public space }\end{array}$ & 31 & 9,8 & 77 & 0,6 \\
\hline 3 Intra-family Murder & 15 & 12,5 & 93 & 0,5 \\
\hline $\begin{array}{l}4 \text { Intra Domestic household murder by } \\
\text { servants or ex-servants }\end{array}$ & 3 & 12,6 & 67 & 1,4 \\
\hline $\begin{array}{l}5 \text { Murder in private context not between } \\
\text { members of that household }\end{array}$ & 7 & 7,3 & 57 & 0,2 \\
\hline $\begin{array}{l}6 \text { Murder in the course of property } \\
\text { crime }\end{array}$ & 8 & 13,9 & 88 & 0,7 \\
\hline $\begin{array}{l}7 \text { Murder of police officer or other } \\
\text { public officer }\end{array}$ & 1 & 8,0 & 100 & 1,4 \\
\hline 8 Murder arisng from attempted rape & 1 & 21,0 & 100 & 2,1 \\
\hline $\begin{array}{l}9 \text { Murder by Police officer (including of } \\
\text { other police officer) }\end{array}$ & 5 & 13,6 & 80 & 0,8 \\
\hline $\begin{array}{l}10 \text { Other Murders/Deaths in suspicious } \\
\& \text { uncommon circumstances }\end{array}$ & 2 & 3,5 & 50 & 0,3 \\
\hline All Types of Murder trials Combined & 82 & 10,5 & 80 & 0,6 \\
\hline
\end{tabular}

about half the average newshole usually devoted to Old Bailey murder cases. Among these, for example, were trials involving the death of a poor boy who fell in front of the Birmingham coach and of a deaf old man run over by a dray, both of which failed to obtain coverage of more than a few lines ${ }^{43}$. Murder indictments arising from fights in public spaces - in the street, pub, etc. - which also very often resulted in a partial verdict of manslaughter or in acquittal, because the death of the victim was not deemed to have been deliberate, present a more complex picture. As Table 3B indicates there were significant differences within this category according to the precise context in which the fight occurred. Fights that lead to the death of one of the protagonists got relatively little coverage if the death followed a formal agreement to strip and fight in rounds. If a death arose from a boxing match fought for money - as it did every couple of years in this period - the trial was unlikely to be reported at all and received at best minimal coverage. Indictments for murder arising from public fights got longer coverage on average if they occurred in the streets and did not follow customary rules, or if they involved the use of lethal weapons such as knives. Deaths during violent riots might also result in much longer reports. The death of Henry Newell in 1788, who was knocked down during a Westminster election riot by a member of the 'Blue and Buff mob', received about four times the average coverage, the prosecution being deeply enmeshed in the politics of the election itself ${ }^{44}$.

43 OBSP, 1788, John Smith (t17880910-54); 1790, Michael Hulcup, t17900915-71. Times, 18 September 1790 .

44 OBSP, 1788, William Wilkins and Richard Gwilt (t17880910-27), Times, 13 and 15 September 1788 . 
Table 3B: Times Coverage of Specific Types of Murder Trial 1785-94

\begin{tabular}{|c|c|c|c|}
\hline Description of crime & $\begin{array}{l}\text { No of } \\
\text { cases in } \\
\text { OBSP }\end{array}$ & $\begin{array}{l}\text { Ave no } \\
\text { of Pages } \\
\text { in OBSP }\end{array}$ & $\begin{array}{l}\text { Ave size } \\
\text { Column } \\
\text { inTimes }\end{array}$ \\
\hline $\begin{array}{l}\text { 1. Accidental death } \\
\text { Accidental death/Murder whilst neglected in custody } \\
\text { Accidental death/Murder gored in bull-running begun by accused } \\
\text { Accidental death/Murder - vehicle accident/dangerous driving } \\
\text { Accidental death/Murder arising from accident with gun } \\
\text { Accidental Death/Murder after poor sick man dumped in street }\end{array}$ & $\begin{array}{l}1 \\
2 \\
4 \\
1 \\
1\end{array}$ & $\begin{array}{r}1,0 \\
9,0 \\
5,0 \\
16,0 \\
11,0\end{array}$ & $\begin{array}{l}0,2 \\
0,4 \\
0,3 \\
0,0 \\
0,5\end{array}$ \\
\hline $\begin{array}{l}\text { 2. Death from fight in public space } \\
\text { Fight related Murder as result of boxing match for money } \\
\text { Fight related Murder arising from fight in street/public space } \\
\text { Fight related Murder arising from a fight in inn/public house etc } \\
\text { Fight related Murder arising from riot/informal crowd punishment } \\
\text { Fight related Murder following agreement to strip \& fight rounds }\end{array}$ & $\begin{array}{r}4 \\
19 \\
3 \\
3 \\
2\end{array}$ & $\begin{array}{r}4,5 \\
10,4 \\
4,0 \\
16,7 \\
13,0\end{array}$ & $\begin{array}{l}0,1 \\
0,8 \\
0,4 \\
0,8 \\
0,4\end{array}$ \\
\hline $\begin{array}{l}\text { 3. Intra-family Murder } \\
\text { Husband murdered wife } \\
\text { Parent or Step-parent kills child } \\
\text { Murder of sibling } \\
\text { Murder of Mother-in-law sheltering runaway wife }\end{array}$ & $\begin{array}{l}9 \\
3 \\
2 \\
1\end{array}$ & $\begin{array}{r}15,4 \\
9,7 \\
7,5 \\
5,0\end{array}$ & $\begin{array}{l}0,7 \\
0,4 \\
0,4 \\
0,4\end{array}$ \\
\hline $\begin{array}{l}\text { 4. Intra household murder by servants } \\
\text { Living-in Servant murders elderly mistress } \\
\text { Murder by ex-servants of member of employer's family } \\
\text { Murder by nurse of employer's child (possibly by neglect) }\end{array}$ & $\begin{array}{l}1 \\
1 \\
1\end{array}$ & $\begin{array}{r}17,0 \\
17,0 \\
4,0\end{array}$ & $\begin{array}{l}3,6 \\
0,7 \\
0,0\end{array}$ \\
\hline $\begin{array}{l}\text { 5. Murder in private } \\
\text { Murder arising from a non-familial fight in domestic environment } \\
\text { Murder in context of prostitution either by or of prostitute/client }\end{array}$ & $\begin{array}{l}5 \\
2\end{array}$ & $\begin{array}{r}5,8 \\
11,0\end{array}$ & $\begin{array}{l}0,2 \\
0,3\end{array}$ \\
\hline $\begin{array}{l}\text { 6. Murder during property crime } \\
\text { Murder by thieves as part of robbery } \\
\text { Murder by thieves of captors after caught theiving }\end{array}$ & $\begin{array}{l}5 \\
3\end{array}$ & $\begin{array}{l}10,2 \\
20,0\end{array}$ & $\begin{array}{l}0,2 \\
1,4\end{array}$ \\
\hline $\begin{array}{l}\text { 7. Murder of police officer } \\
\text { Murder of theif-taker attached to police office }\end{array}$ & 1 & 8,0 & 1,4 \\
\hline $\begin{array}{l}\text { 8. Murder arisng from rape } \\
\text { Murder of victim when attempted rape resisted }\end{array}$ & 1 & 21,0 & 2,1 \\
\hline $\begin{array}{l}\text { 9. Murder by Police/Press Gang officer } \\
\text { Murder by Police officer in course of duty } \\
\text { Murder by Press gang member during operations }\end{array}$ & $\begin{array}{l}2 \\
3\end{array}$ & $\begin{array}{r}8,5 \\
17,0\end{array}$ & $\begin{array}{l}0,4 \\
1,1\end{array}$ \\
\hline $\begin{array}{l}\text { 10. Other Murders/Deaths in suspicious circumstances } \\
\text { Shot mad intruder to Mistresses house in self defence } \\
\text { Indictment for murder no detail }\end{array}$ & $\begin{array}{l}1 \\
1\end{array}$ & $\begin{array}{l}6,0 \\
1,0\end{array}$ & $\begin{array}{l}0,6 \\
0,0\end{array}$ \\
\hline
\end{tabular}


Murders that occurred in private, i.e. in domestic dwellings, and did not involve the murder of fellow family members also got extremely low coverage (Table 3A, section 5) and were the only category in which less than two thirds of trials were reported. By contrast, intra-family murders were almost always reported in The Times but domestic murders of family members received on aggregate slightly less coverage than the norm for all types of murder. However, as Table 3B indicates, husbands murdering their wives were given, on average, slightly greater coverage, unlike other intra familiar murders. Trials involving the killing of wives happened about once a year and were often covered fairly routinely, but occasionally a particularly brutal attack, such as that by a pork butcher in 1791 who gave his wife multiple stab wounds, was given greater coverage ${ }^{45}$.

Five broad categories of murder trial attracted above average coverage in The Times. Murder during the course of a property crime received slightly higher coverage especially if, as was the case with a gang of pickpockets in 1786, the murder had resulted from the thieves' resisting arrest ${ }^{46}$. The one murder of a police officer - a thief-taker killed while trying to make an arrest - got more than twice the average coverage $^{47}$. However, murders by police officers were not necessarily well covered - the exception being the indictment of William Whiteway for attempting to murder the captain of a press gang in 1787. Whiteway had a warrant for the captain's arrest for assaulting a young girl, but when 'desired by Whiteway to go along with him' the Captain replied 'he would not go with any $d--d$ bloody $b--r$ of a runner' and threatened him with a bludgeon. Whiteway, intimidated by the presence of the whole of the Captain's gang then shot at the Captain and was arrested for attempted murder. Not surprisingly given the popular dislike of press gangs, Whiteway's acquittal received considerable coverage ${ }^{48}$. The other two categories of murder trial that were given large amounts of space (three to four times the average) involved either servants or ex-servants killing masters (as Henrietta Radbourne did) or, in one case, a murder arising from an attempted rape. The latter case, in which a woman was killed whilst resisting a rapist, may also have got extensive coverage because of the added interest created by the fact that the accused was described as 'a mulatto' ${ }^{, 9}$.

In other types of case, however, the fact that the victim was a woman did not in itself generate greater newsworthiness. As Table 4 indicates the gender of the victim seems, on average, to have made virtually no difference to the length of The Times trial report. However, when the person accused of murder was a woman the average level of coverage was considerably higher. Female murderers were sufficiently interesting to be given around double the average coverage in this period. This was not because their trials were longer. If the length of the Old Bailey Sessions Papers reports is anything to go by, murder trials in which men were the accused took up very slightly more Old Bailey Sessions Papers pages than those in which a woman was the offender. Rather it was the gender of the accused that appears to have been the key, and this was especially likely to be the case if a woman killed a man. The

\footnotetext{
45 OBSP, 1791, George Dingler (t17910911-1), Times, 17 September 1791. 1786.

47 OBSP, 1789, William Power (t17890909-109), Times, 12 September 1789.

48 OBSP, 1787, William Whiteway (t17871024-19), Times, 26 October 1787.

49 OBSP, 1786, John Hogan (t17860111-1), Times, 14 January 1786.
} 
Table 4: Gender Dimensions to Murder Reporting in The Times Newspaper 1785-94

\begin{tabular}{|l|c|c|}
\hline & Number of cases & Average Column Length \\
\hline Male on Male & 56 & 0,56 \\
Male on Female & 19 & 0,55 \\
Female on Male & 1 & 2,40 \\
Female on Female & 6 & 0,83 \\
All & 82 & 0,60 \\
\hline Male Accused & 75 & 0,56 \\
Female Accused & 7 & 1,10 \\
Male victim & 57 & 0,59 \\
Female victim & 25 & 0,60 \\
All & 164 & 0,60 \\
\hline
\end{tabular}

only trial in which a woman was tried for causing the death of a man that can be found in the Old Bailey Sessions Papers during the ten years sampled here - which involved the stabbing of a man in an alley in Whitechapel - generated the third longest newspaper Old Bailey report of the whole decade, despite the fact that the female accused had merely aided and encouraged her husband to commit the murder $^{50}$.

\section{V}

Thus a complex range of factors determined the depth of coverage The Times gave to any specific murder trial in the 1780s and 1790s. Some factors, of course, would have had little to do with the trial itself. On a slow news day, longer reports no doubt got in by default. On a day when exciting news had arrived from France, or a long awaited parliamentary debate had taken place, even the most newsworthy of murders might get short shrift. However, taking the decade as whole, a clear pattern emerges. At one end of the scale almost all the ten murder trials The Times does not even seem to have bothered reporting, and many of those it gave only a small amount of column space to, tended to include only plebeian or low status actors and to involve incidents that were not perceived as threatening to the broader population. Boxing matches for money that ended in a contestant's death were not usually thought worth reporting as were a number of incidents in which the death of the low status victim was difficult to relate to a specific motive or circumstance. Among those trials that were reported but failed to obtain coverage of more than a few lines can be found, for example, the murder of a mulatto wife by her white husband, the killing of a pickpocket who resisted being subjected to the common informal punishment of ducking in a pond, a Jew knocked down by a madman on Waltham Bridge $^{51}$, and several deaths occasioned by unlucky falls and head injuries during

50 OBSP, 1792, Samuel Taylor and Jane Taylor otherwise Morgan (t17920113-53), Times, 14 January 1792. The very fact that so few women were accused of murder would have given such cases a scarcity value and thus made them more likely to be fully reported.

51 OBSP, 1789, William Woodcock (t17890114-1), Times, 19 January 1789; OBSP, 1794, Robert Andrews (t17940917-47), Times, 20 September 1794; OBSP, 1790, Robert Natcot (t17890114-1), Times, 20 September 1790. 
drunken fights between Irishmen or other men from labouring backgrounds ${ }^{52}$. Cases of what many would have thought of as manslaughter rather than murder because they were occasioned by recklessness or accident were particularly likely to get short coverage, or sometimes none at all, if they involved the poorer inhabitants of the metropolis. It was not death by the hand of another itself that was big news. Not even the death of a wife at the hands of her husband. It was those murders that occurred in a specific context in which other newsworthy elements were involved that got most heavily reported. If a police officer was killed or did the killing; if the hated press gangs were involved; if the murderer was a stranger who was trying to rob the victim; if the case had a sexual element or played into women's fear of rape; if it aroused middling men and women's deep seated anxieties about their relationships with the many servants they employed, or if the case involved (as it rarely did) a particularly high status victim or accused it would usually get much heavier coverage.

The patterns uncovered here for the 1780s and 1790s exhibit many very interesting parallels with the modern newspaper reporting policies in relation to murder analysed recently by Peelo, Francis, Southill et $a l^{53}$. For example, in the British national newspapers between 1993 and 1996 it was also the case that murders were more likely to get the attention of the newspapers if the victim was a policemen, or a person of higher status; if the murder occurred during a robbery or was related to a sexual assault or an arson attack; or if the accused was the victim's husband. Equally a murder was less likely to occupy the time of the newspapers if the victim was very poor; if the murder arose from a routine quarrel; if the murder was the result of recklessness or had an accidental element, or if the cause of death was kicking and hitting rather than involving the use of a weapon such as a gun. It is also interesting that in The Times in the 1990s just as in The Times in the 1790s a murder was more likely to be reported if the accused was a female ${ }^{54}$.

However, there are also some significant discontinuities in the murder reporting policies of the newspapers sampled in these two periods. In the 1990s cases involving female victims were considerably more likely to be reported than those involving male victims. In The Times between 1785 and 1794 this was not the case. Equally, in the 1990s murder cases involving the neglect of children or cases in which professional boxers died as a result of the blows they received in an organised bout got much more extensive coverage than similar incidents appear to have done two hundred years earlier. Other features of reporting rates among the 2,600 murders that constitute the 1990s national murder sample constructed by Peelo et al cannot be studied for the 1780s and 1790s because the sample is too small to include any examples, or because no systematic information is available on key variables. For example, it remains unclear whether murders committed by young people in their early teens or pre-teens would have got as much coverage in the 1780s as they did in the 1990s, because no precise information on the age of either accused or the victim is available for the late eighteenth century. Equally, the possibility that the 1990s pattern of much greater coverage for murders in which the victim was aged 4-16 also

52 For example-OBSP, 1792, Francis Hubbard et al. (t17920329-26), Times, 31 March 1792.

53 Peelo, Francis, Soothill, Pearson, Ackerly (2004).

$54 \quad$ Ibid.p. 265 - in Times there was a 25 per cent difference, but in the other two papers studied for the 1990 s the cases involving female accused were only slightly more likely to be reported. 
occurred in the 1790 s cannot be systematically tested, although the major coverage occasionally given to the murder of apprentices by their masters or mistresses suggests there may also have been considerable continuity in this area ${ }^{55}$. The nature of the newspapers themselves changed drastically during these two centuries and the data for the 1780s/90s and for the 1990s are not always compatible. The later, for example, included murders from all over England and are based on a study of the extent of coverage rather than of its intensity, which has been the main focus here. However, while it would clearly be very unwise to argue that newspaper policies on murder reporting were static during these two centuries, the many continuities observable in those policies suggest that the ways the newspapers constructed public narratives of, and understandings about, homicide were by no means completely dissimilar in these two periods.

\section{VI}

One other important dimension of newspaper selection policies that also comes out clearly from this study of murder trials in the 1780s and 1790s, is that there was a very high correlation between the penalty, or lack of penalty, imposed by the court and both the likelihood that the trial would be reported in the newspapers and the amount of column inches that would be devoted to it if it was. Almost all the murder trials that ended in a death sentence were reported, but only three-quarters of those that ended in acquittal or in a partial verdict of manslaughter (which resulted in the relatively minor punishments of fining, branding or imprisonment) reached the pages of The Times. Trials that ended in an acquittal or a partial verdict also only attracted on average about half a column of coverage. Those that ended in a conviction and an automatic death sentence averaged about double that coverage and often took up more than a full column ${ }^{56}$.

This correlation may also help to explain the patterns of trial reporting across all types of trial found in Tables 1 and 2. The possibility of an execution had a major effect on the perceived newsworthiness not only of murder trials but also of other trials in which the charge was a capital one. This may well partly explain why forgery cases attracted so much attention. Pardoning rates were very low in such cases and a death sentence usually meant death ${ }^{57}$. It was not only death by murder that attracted the newspapers attention. The likelihood that the trial of a forger - who was frequently a relatively respectable individual - would end in a state sponsored killing also created added interest. Two of the most heavily reported trials of the later eighteenth century, which kept the newspapers in copy for months - those of the Perreaus and of Dr Dodd (who was the King's Chaplain) - involved relatively high status individuals who eventually went to the gallows for forgery ${ }^{58}$. The same "shadow of the gallows' factor may also have been behind the larger coverage in cases of

55 Ibid., pp. 262-265. On the growing publicity given to the deaths of apprentices at the hands of their masters or mistresses in the late eighteenth century see Lane (1996, p. 225).

56 These figures are based on those trials that were included in the OBSP. For two years at the beginning of the 1790s trials ending in acquittals were excluded from the OBSP, see Devereaux (1996, pp. 492-493), but since these comparisons are based on proportions within those trials that were reported they are not affected by this temporary omission.

57 Beattie (1986, p. 433); King (2000, p. 274).

58 Andrew, McGowen (2001); Radzinowicz (1948, pp. 450-472). 
arson and to a lesser extent in highway robbery trials, where the chances of reprieve were also lower than for run of the mill capital crimes. The modern obsession with murder reports and trials and the relative neglect in the modern national media of arson, forgery etc may in part be because death at the hands of the penal system is no longer a consequence of conviction for these crimes. Murder may not have always been prime material for longer news coverage in the late eighteenth century but death was. Death on the gallows was still public and dramatic and the prospect of such a drama, particularly if it might involve men, or preferably women, of respectable status, was a key criterion of newsworthiness.

\section{VII}

In this paper I have aimed to explore two related issues - the selection policies of the eighteenth-century newspapers and their specific approaches to crimes of lethal violence. To do so I have focussed on a source that was becoming extremely useful to the newspaper proprietors of late eighteenth-century England - the Old Bailey trial. From the point of view of those who managed the newspaper production process of the biggest section of the London newspaper market - the dailies Old Bailey trials were a very convenient source of news. For a week or a week and a half every 6 weeks or so these trials, which brought together all the major detected offenders of the metropolis, were on tap as a news resource. If there did not appear to be enough news that day more of the reports available from those who made a living attending and summarising Old Bailey trials could usually be obtained fairly easily. Equally on a hot news day they could be dropped or heavily edited. For a daily paper in particular the regular day by day rhythm of the Old Bailey when it was in session was a very distinct advantage. Not surprisingly therefore the amount of crime news that was printed by the dailies rose very considerably during Old Bailey sessions. Trial reporting was still highly selective, however. Even on a relatively slow news day, there was not enough room to report more than a relatively small minority of trials, and this therefore makes Old Bailey trial reports an ideal place in which to analyse contemporary ideas about the newsworthiness of different types of crime and criminal.

To return to our core question. What types of crime were considered most newsworthy in this period and in particular what role did violence play in the creation of a newsworthy story? In the process of exploring the selection processes which the newspapers used in relation to Old Bailey trials a number of themes have emerged. At the simplest level we have identified the kinds of stories that were most easily and frequently ignored - trials involving simple theft; trials in which all the actors and the milieu was plebeian; trials with no females in them; trials with no element of violence and trials which offered no prospect that the state's ultimate right to make a lethally violent penal response would be exercised at the end. We have also identified individual trials and certain types of trial that clearly tuned into story lines and situations which those who selected the news believed were highly newsworthy. The baseline, of course, was to find stories with plenty of drama. Stories that were not only different to the norm but also different in interesting ways - stones thrown at the King's coach, arson attacks that nearly set a whole street alight etc. Beyond this however, it is also possible to spot more specific criteria many of which can also be found in modern studies of law and order news selection. If a known celebrity 
was involved as accused and/or if a trial fell into a category of offence, such as forgery, that usually involved accused men and women of higher status - publication of the trial tended to become a priority. Equally if there was a sexual context a woman murdered because she refused to be raped, an ageing countess seduced to relieve her of her worldly goods - the trial was usually selected for lengthy coverage, on the assumption that even if the sexual activity itself could not be fully reported, the trial would still titillate or amuse. Stories that played into the more socially specific fears of eighteenth-century middling and gentry families about issues such as their vulnerability to physical attack from the domestic servants they regularly locked themselves in with at night would also make potent news themes and might be followed through the entire judicial process from committal to dissection. Equally, stories that played into the fears of all social groups about the risks that everyday life in the metropolis might bring - about street robberies that could end in fatal violence, or about irresponsible drivers who caused fatal accidents, might also prove popular with newspapers, although if relatively large numbers of similar trials occurred (such as regular fatalities due to everyday road accidents) their perceived newsworthiness would fall.

Yet while many of these themes have a very modern air about them and, as we have seen in relation to murder, there are many parallels with modern patterns of crime and trial reporting, it is equally clear that when we look at all the different types of offences tried at the Old Bailey there are major differences in newspaper selection policies. In particular the role of violence as an indicator of newsworthiness played itself out rather differently in the late eighteenth century. Then, as now, trials that involved lethal violence were much more likely to be reported than any other category, but the modern obsession with murder trials was not automatically replicated in the eighteenth century. Modern work on the media reporting of crime has highlighted the ways that both newspapers and other media focus primarily on violent crime and particularly on murder (as do fictional television dramas and 'true crime' books). The detailed content analyses completed by modern criminologists since the Second World War have found that crimes of violence are featured disproportionately in news reports compared to their incidence in official crime statistics or in surveys of victims experiences. They have also found that British newspapers have devoted about a third of their crime coverage to murder related stories ${ }^{59}$. This was not the case in the eighteenth century. Many murder trial reports - even those involving deliberate killings which were not simply manslaughter cases in disguise - got much less column space than might have been expected based on modern experience. Much longer coverage was frequently given to forgery, coining, and arson cases, for example, or to individuals such as Barrington who had not been involved in violence of any sort. This overall pattern - the much more central part played by cases that did not involve lethal violence in late eighteenth-century trial reporting than its equivalent two hundred years later - is in some ways a surprising finding. However, at least four related explanations stand out as potentially important in any exploration of the complex factors that lie behind it.

59 Williams, Dickinson (1993, pp. 35-40). They quote, for example, Ditton and Duffy's 1980s study of Scottish crime reporting which indicated that 46 per cent of crime news stories involved violent and sexual crime while only 2 per cent of police recorded crime in the same area related to these categories of offence. 
First, the relative absence of murder as the key story line in the eighteenth century may, in part, have been a supply side problem. With a low murder indictment rate and a city only a sixth of its modern size, there may simply not have been enough murder trials to go round in late eighteenth-century London. Murder indictment rates in the metropolis were at one of the lowest ever points in their history by the $1790 \mathrm{~s}^{60}$. There were only about eight murder trials a year in the period studied here and relatively few reports of additional unsolved murders can be found in the newspapers. Secondly, it is possible that in a less well insured era such as this, when fire and other emergency services were also far less efficient, fears about other kinds of risk - about fire in a densely populated area, about being defrauded by forgery or about being robbed of relatively large sums of money - may well have given greater emotional resonance to other forms of crime and to their associated trials than they do today. Thirdly, at a more technical level, the number of columns given over to different types of trial, which has been used here as a rather crude indicator of newsworthiness, would sometimes have been affected by the fact that some trials for arson, forgery etc lasted longer than average because evidence sufficient to prove the charge was more difficult to present quickly. In forgery cases in particular this would have given the reporters more potential material to work with.

Finally, and most importantly perhaps, a vital role in insuring that trial reports did not focus so heavily on murder was almost certainly played by the capital code. The fact that most forgery and arson trials (and a considerable proportion of highway robbery and coining trials) might not only end in the drama of a death sentence but also in a desperate drawn-out dangling death in full view of the public, added vital drama to these categories of trial which is totally absent today. Even if as many murders went undetected (and therefore not indicted) as were tried at the Old Bailey, in any given year 1785-1794 many more people were killed by the state on the gallows outside Newgate than were killed by the people of London. In the 1780s an average of 50 a year died on the fatal tree ${ }^{61}$, more than six times the number of murder victims whose deaths created a murder trial at the Old Bailey. Given this massive imbalance it is not surprising that the newspapers focussed on all the types of trial that were likely to produce an execution and not just those involving murder. The state was the main murderer in late eighteenth-century London and its activities had a major impact on the kinds of trials that were deemed newsworthy. The bloody code not only influenced the way people thought about the criminal justice system but also helped to shape in vital ways the forms in which crime was reported.

It is easy to be very pessimistic about the degree to which eighteenth-century newspaper selection mechanisms can be identified, let alone explained. In a recent overview of newspaper reporting of crime and justice issues, for example, Elizabeth Foyster suggested that 'how and why certain news stories were selected ... remain largely unanswerable questions for historians of the eighteenth century ${ }^{62}$. However, through a detailed investigation of the ways in which the London newspapers reported Old Bailey trials, which were virtually the only subgroup of law and order news items for which we have an accurate record of the cases they selected from, it has been possible to identify some of the core ideas about newsworthiness that

\footnotetext{
60 Shoemaker (2001, p. 192).

${ }^{61}$ Gatrell (1994, p. 616).

62 Foyster (2007, p. 11).
} 
newspaper selection mechanisms were based upon in the late eighteenth century. Moreover, in the process we have unravelled many continuities, and some important discontinuities, between eighteenth-century newspaper editors' ideas about the role of violence in creating a newsworthy story and the parallel notions used by modern crime reporters. Across these two centuries of massive social and economic change in which the nature of newspapers themselves and of the criminal justice system have also undergone major transformations, those who manufactured crime and justice news continued to use many of the same criteria of newsworthiness, whilst at the same time those criteria have also undergone important changes as a result of broader cultural shifts such as the repeal of the capital code.

Peter King
International Centre For Comparative Criminological Research
Walton Hall
The Open University
UK - Milton Keynes MK7 6AA
P.J.R.King@open.ac.uk

\section{BIBLIOGRAPHY}

Abbott, J., The Press and the Public Visibility of Nineteenth-Century Criminal Children, in Rowbottom, J., Stevenson, K. (eds), Criminal Conversations; Victorian Crimes, Social Panic and Moral Outrage, Columbus Ohio, 2005.

Andrew, D., McGowen, R., The Perreaus and Mrs Rudd; Forgery and Betrayal in Eighteenth-Century London, Berkeley, 2001.

Barker, H., Newspapers, Politics and Public Opinion in Late Eighteenth-Century England, Oxford, 1998.

Beattie J., Crime and the Courts in England 1660-1800, Oxford, 1986.

Bondeson J., The London Monster. A Sanguinary Tale, Pennsylvania, 2001.

Carter Wood, J., Violence and Crime in Nineteenth-Century England. The Shadow of our Refinement, London, 2004.

Chibnall, S., Law and Order News, London, 1977.

Cohen, S., Young J. (eds), The Manufacture of News. Deviance, Social Problems and the Mass Media, London, 1973.

Conley, C., Certain Other Countries; Homicide, Gender and National Identity in Late Nineteenth-Century England, Ireland, Scotland and Wales, Columbus Ohio, 2007.

Davis J., The London Garotting Panic of 1862. A Moral Panic and the Creation of a Criminal Class in Mid-Victorian England, in Gatrell, V., Lenham, B., Parker, G., Crime and the Law: A Social History of Crime in Western Europe since 1500, London, 1980.

Devereaux, S., The City and the Sessions Paper: «Public Justice» in London, 1770-1800, Journal of British Studies, 1996, 35, pp. 466-503.

Devereaux S., The Fall of the Sessions Paper. The Criminal Trial and the Popular Press in Late Eighteenth-Century London, Criminal Justice History, 2003, 18, pp. 57-88.

Devereaux S., From Sessions to Newspaper? Criminal Trial Reporting, the Nature of Crime, and the London Press, 1770-1800, London Journal, 2007, 32, pp. 1-12.

Emsley C., Crime, Police and Penal Policy; European Experiences 1750-1940, Oxford, 2007. 
Emsley C., Violent Crime in England in 1919: Post-War Anxieties and Press Narratives, Continuity and Change, 2008, 23, pp. 173-195.

Foyster E., Introduction: Newspaper Reporting of Crime and Justice, Continuity and Change, 2007, 22, pp. 9-12.

Fishman M., Crime Waves as Ideology, in Cohen, S., Young, J. (eds), The Manufacture of News (Second Edition, London), 1981, pp. 98-117.

Gatrell V., The Hanging Tree; Execution and the English People 1770-1868, Oxford, 1994. Jewkes, Y., Media and Crime, London, 2004.

Katz, J., What Makes Crime News?, Media, Culture and Society, 1987, 9, pp. 47-75.

King, P., Newspaper Reporting, Prosecution Practice and Perceptions of Urban Crime; the Colchester Crime Wave of 1765, Continuity and Change, 1987, 2, pp. 423-454.

King, P., Crime, Justice and Discretion in England 1740-1820, Oxford, 2000.

King, P., Moral Panics and Violent Street Crime 1750-2000: A Comparative Perspective, in Godfrey, B., Emsley, C., Dunstall, G. (eds), Comparative Histories of Crime, Cullompton, 2003.

King, P., Crime and the Law in England 1750-1840; Remaking Justice from the Margins, Cambridge, 2006.

King, P., Newspaper Reporting and Attitudes to Crime and Justice in Late Eighteenth and Early-Nineteenth Century London, Continuity and Change, 2007, 22, pp. 73-112.

King, P., Sex, Strangulation and Censorship at the Old Bailey in the Late Eighteenth Century; the case of Susannah Hill (forthcoming).

Lane, J., Apprenticeship in England 1600-1914, London, 1996.

McGowen, R., A Powerful Sympathy: Terror, the Prison and Humanitarian Reform in Early Nineteenth-Century Britain, Journal of British Studies, 1986, 25, pp. 312-334.

McGowen, R., Punishing Violence, Sentencing Crime, in Armstrong, N., Tennenhouse, L. (eds), The Violence of Representation. Literature and the History of Violence, London, 1989.

McGowen, R., The Problem of Punishment in Eighteenth-Century England, in Devereaux, S., Griffiths, P. (eds), Penal Practice and Culture 1500-1900; Punishing the English, Basingstoke, 2004.

McGowen, R., Cruel Inflictions and the Claims of Humanity in early Nineteenth-Century England, in Watson, K. (ed.), Assaulting the Past; Violence and Civilisation in Historical Context, Cambridge, 2007.

McKenzie, A., Tyburn's Martyrs; Execution in England 1675-1775, London, 2007.

McMahon, R., For Fear of the Vengence: The Prosecution of Homicide in Pre-Famine and Famine Ireland, in McMahon, R. (ed.), Crime, Law and Popular Culture in Europe 15001900, Cullompton, 2008.

Pearson, G., Hooligan; A History of Respectable Fears, London, 1983.

Peelo, M., Francis, B., Soothill, K., Pearson, J., Ackerly, E., Newspaper Reporting and the Public Construction of Homicide, British Journal of Criminology, 2004, 44, pp. 256-275.

Radzinowicz, L., A History of English Criminal Law; Volume 1 The Movement for Reform, London, 1948.

Rawlings, P., Crime and Power; A History of Criminal Justice 1688-1998, Harlow, 1999.

Reiner, R., Media Made Criminality; The Representation of Crime in the Mass Media, in Maguire, M., Morgan, R., Reiner, R. (eds), The Oxford Handbook of Criminology, Third edition, Oxford, 2002.

Rogers, N., Confronting the Crime Wave: The Debate over Social Reform and Regulation 1749-1753, in Davison, L., Hitchcock, T., Keirn, T., Shoemaker, R. (eds), Stilling the 
Grumbling Hive; The Response to Social and Economic Problems in England 16891750, Stroud, 1992.

Roshier, B., The Selection of Crime News by the Press, in Cohen, S., Young, J. (eds), The Manufacture of News, Second Edition, London, 1973.

Ruff, J., Violence in Early Modern Europe 1500-1800, Cambridge, 2001.

Shoemaker, R., Male Honour and the Decline of Public Violence in Eighteenth-Century London, Social History, 2001, 26, pp. 190-208.

Shoemaker, R., The London Mob; Violence and Disorder in Eighteenth-Century England, London, 2004, pp. 275-300.

Shoemaker, R., The Old Bailey and the Representation of Crime and Criminal Justice in Eighteenth-Century London, Journal of British Studies, 2008, 47, pp. 559-580.

Smith, G., The State and the Culture of Violence in London 1760-1840, Ph.D., University of Toronto, 1999.

Snell, E., Representations of Criminality and Victimisation in Provincial Newspapers: The Kentish Post 1717 to 1767, Southern History, 2005, 27, pp. 48-75.

Snell, E., Discourses of Criminality in the Eighteenth-Century Press: the Presentation of Crime in the Kentish Post 1717-1767, Continuity and Change, 2007, 22, pp. 13-47.

Spierenburg, P., Violence and the Civilising Process; Does it Work, Crime, Histoire et Sociétés/Crime, History and Societies, 2001, 5, pp. 87-105.

Statt, D., The Case of the Mohocks: Rake Violence in Augustan London, Social History, 1995, 20, pp. 179-199.

Walkowitz, J., City of Dreadful Delight; Narratives of Sexual Danger in Late-Victorian London, London, 1992.

Wardle, C., «It Could Happen to you». The Move towards «Personal» and «Societal» Narratives in Newspaper Coverage of Child Murder 1930-2000, Journalism Studies, 2006, 7, pp. 515-533.

Werkmeister, L., A Newspaper History of England 1792-1793, Nebraska, 1967.

Williams, P., Dickinson, J., Fear of Crime: Read all about it? The Relationship Between Newspaper Crime Reporting and Fear of Crime, British Journal of Criminology, 1993, 33 , pp. 35-56. 